\title{
APPORTIONMENT OF DAMAGES FOR CONTRIBUTORY NEGLIGENCE: THE CAUSAL POTENCY CRITERION
}

\author{
JAMES GOUDKAMP $^{*}$ AND LEWIS KLAR ${ }^{* *}$
}

\begin{abstract}
The courts in several common law jurisdictions have adopted a causal potency criterion for the purposes of apportioning damages for contributory negligence. It has recently been suggested that Canadian courts should follow suit. This article explores the causal potency criterion. It is argued that the criterion has been left unexplained with the result that it is an empty concept. Moreover, no compelling justification has been offered in support of taking causal potency into account. Accordingly, adopting the causal potency criterion would be a retrograde step for Canadian tort law.
\end{abstract}

\section{TABLE OF Contents}

I. INTRODUCTION . . . . . . . . . . . . . . . . . . . . 849

II. THE LAW . . . . . . . . . . . . . . . . . . . . . . . . . . . . 852

A. Great Britain . . . . . . . . . . . . . . . . . 853

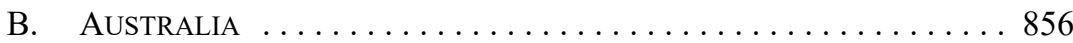

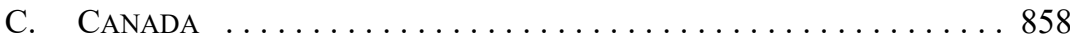

D. United STATES . . . . . . . . . . . . . . . . . . . . . . . . . . . 859

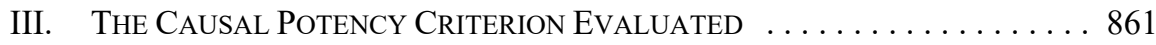

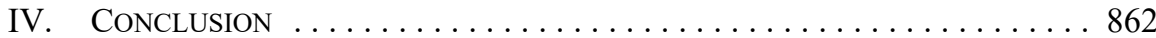

\section{INTRODUCTION}

At common law, contributory negligence was fatal to the plaintiff's cause of action. It was irrelevant that the plaintiff's share of the responsibility for the damage was insignificant relative to the defendant's. ${ }^{1}$ Any causally relevant fault by the plaintiff with respect to his own safety precluded recovery. This "vicious" and "harsh"3 all-or-nothing doctrine led to formidable and well-documented difficulties. In an attempt to confine the rule, judges devised numerous supplementary principles that allowed the plaintiff to obtain full damages despite his contributory fault. The most notorious of these additional rules was the "last clear chance" doctrine. ${ }^{4}$ Pursuant to this doctrine, the plaintiff was permitted to recover if the defendant had the last clear chance to prevent the damage. When this doctrine was enlivened, the plaintiff's contribution to the damage was ignored and responsibility for it was cast solely on the defendant. However, these bolt-on rules were generally difficult to apply and led to

* Fellow and Tutor in Law, Keble College, Oxford; Associate Professor, Oxford Law Faculty; Senior Honorary Research Fellow, Faculty of Law, University of Western Australia; Professorial Fellow, School of Law, University of Wollongong; barrister, 7 King's Bench Walk.

** QC. Professor Emeritus, University of Alberta. We are grateful to David Cheifetz for his helpful comments on a draft of this article.

$1 \quad$ Cayzer, Irvine \& Co v Carron Co (1884), 9 App Cas 873 (HL (Eng)) ("the rule of law is that if there is blame causing the accident on both sides, however small that blame may be on one side, the loss lies where it falls" at 881).

2 Robert Stevens, "Should Contributory Fault be Analogue or Digital?" in Andrew Dyson, James Goudkamp \& Frederick Wilmot-Smith, eds Defences in Tort (Oxford: Hart, 2015) 247 at 255.

3 Malcolm M MacIntyre, "The Rationale of Last Clear Chance" (1940) 53:8 Harv L Rev 1225 at 1225.

$4 \quad$ See Davies v Mann (1842), 152 ER 588 (this decision is often cited as the source of this doctrine, which is also called the "last opportunity" rule). 
unpredictable results. William Prosser lashed out at the last clear chance doctrine as "one of the worst tangles known to the law." "These rules also did nothing to address the basic problem, namely, the fact that the law threw responsibility for the entirety of the damage on just one party although both parties had contributed to it. In all likelihood, juries simply sidestepped them and apportioned damages informally. ${ }^{6}$

In most jurisdictions, this impasse was broken by statute in the first half of the twentieth century. The impetus for change seems to have come principally from the increased use of motor vehicles and the associated rise in road accidents. ${ }^{7}$ The political concern was that substantial numbers of accident victims should not be left entirely uncompensated by reason of their contributory negligence. Although the relevant legislation varies significantly from jurisdiction to jurisdiction, most of the statutes provide, at bottom, that contributory negligence will not result in the failure of the plaintiff's action but, instead, that his damages will be reduced. The relevant stipulation is generally referred to as the "apportionment provision." $" 8$

The enactment of the apportionment legislation was undoubtedly one of the most important developments in the history of tort law. ${ }^{9}$ It is difficult to think of many other changes of commensurate significance. The statutes have affected and will continue to affect countless cases. ${ }^{10}$ Apportioning damages is bread-and-butter work of first instance courts throughout the common law world, ${ }^{11}$ and the provision doubtlessly exerts a powerful effect on settlement negotiations. ${ }^{12}$ Anyone who has even passing familiarity with the practical operation of the tort system knows that defendants contend virtually by default that the plaintiff's damages should be reduced for contributory negligence.

In view of the undoubted and immense significance of the apportionment legislation, it is surprising how little is known about the process of apportionment, both as a matter of theory and practice. The subject has rarely been addressed in the literature and certainly not

William L Prosser, "Comparative Negligence” (1953) 41:1 Cal L Rev 1 at 7.

John G Fleming, The Law of Torts, 9th ed (Sydney, Austl: Law Book, 1998) ("juries tended to mitigate the harshness of the law by frequently apportioning behind the accommodating screen of a general verdict which gave little scope for appellate review" at 305).

7 For a historical excursus, see Jenny Steele, "Law Reform (Contributory Negligence) Act 1945: Collisions of a Different Sort" in TT Arvind \& Jenny Steele, eds, Tort Law and the Legislature: Common Law, Statute and the Dynamics of Legal Change (Oxford: Hart, 2013) 159 especially at 164. A similar story can be told about the common law rule that there could be no contribution between joint tortfeasors. The origin of this principle is usually said to be Merryweather v Nixan (1799), 101 ER 1337. The rule has been reversed by statute (the current British legislation is the Civil Liability (Contribution) Act 1978 (UK), c 47). The Canadian law is described in Lewis N Klar, Tort Law, 5th ed (Toronto, Ont: Carswell, 2012) at 567-82.

9 The apportionment legislation "is as important for tort law as was the coming of insurance": Guido Calabresi \& Jeffrey O Cooper, "New Directions in Tort Law" (1996) 30:3 Val U L Rev 859 at 868.

10 An empirical analysis of the operation of the contributory negligence doctrine in England and Wales is offered in James Goudkamp \& Donal Nolan, "Contributory Negligence in the Twenty-First Century: an Empirical Study of First Instance Decisions" (2016) 79:4 Mod L Rev 575.

11 Steele, supra note 7 ("the [contributory negligence] defence is used on a daily basis" at 165).

12 According to one study of settlements, the apportionment legislation was "extensively used" and taken into account in 45 percent of claims studied: Donald Harris, "Claims for Damages: Negotiating, Settling or Abandoning" in Donald Harris et al, eds, Compensation and Support for Illness and Injury (Oxford: Clarendon Press, 1984) 79 at 91. 
at any length. ${ }^{13}$ Scholars usually simply identify the factors that judges take into account in determining the extent to which damages should be reduced. ${ }^{14}$ It is widely accepted throughout the common law world that one relevant factor in this regard is the parties' relative blameworthiness. This criterion requires consideration of the extent to which each party took less care than the reasonable person in their position would have taken. The purpose of this article is to assess the merits of an additional criterion that is also relevant in many jurisdictions: the causal potency of the parties' respective acts.

The article begins by delineating the law concerning the causal potency criterion in Great Britain, Australia, Canada, and the United States respectively. The analysis will reveal that this criterion features in all of these legal systems except for Canada. It seems that momentum is building for the law in Canada to be brought into line in this regard with that elsewhere. The Manitoba Law Reform Commission recently recommended that causal potency be made relevant to apportionment. It wrote: "[A] more flexible approach is warranted.... [T] he modern purpose of apportionment legislation is to promote fairness and justice between the parties. Apportionment based on both blameworthiness and causation, as the court finds just and equitable, will help to promote this statutory purpose in all cases." $" 15$

In this article we argue against this recommendation. Implementing it would be a retrograde step. The causal potency criterion is deeply problematic. We are hostile to it for numerous reasons. It has never been satisfactorily explained what causal potency means and, as such, the criterion is merely an empty label. Because the concept is vacuous, judges in jurisdictions that adopt it, as we will show, probably do not apply it when apportioning damages. In all likelihood, therefore, if the recommendation of the Manitoba Law Reform Commission were acted upon, it would result in a pointless addition to Canadian law. Most fundamentally, no compelling justification for taking account of causal potency has ever been offered, and we doubt that one could be devised. Accordingly, it is in fact other jurisdictions that should embrace the Canadian approach.

We are not the first commentators to doubt the sense of the causal potency criterion. At the dawn of the age of apportionment, Glanville Williams contended: "To attempt to apportion damages by reference to degree of participation in the chain of causation is a hopeless enterprise, for it has no necessary connection with anything that would appeal to

13 It seems likely that the lack of academic interest in the apportionment of damages for contributory negligence is attributable to the fact that apportionment is an issue for trial courts rather than appellate courts. It is a well-established principle that appellate courts should interfere only exceptionally with determinations regarding apportionment: Jackson v Murray, [2015] UKSC 5, [2015] 2 All ER 805 at 814 , Lord Reed [Jackson]. Glanville Williams wrote that "[i]t is because the apportionment of blame is so much a matter of individual feeling that appeals are restricted": Glanville Williams, Joint Torts and Contributory Negligence: A Study of Concurrent Fault in Great Britain, Ireland and the Common-Law Dominions (London, UK: Stevens \& Sons, 1951) at 391. A similar point is made by Dan B Dobbs, Paul T Hayden \& Ellen M Bublick, The Law of Torts, 2nd ed, vol 3 (Saint Paul, Minn: West, 2011) 3 at 103. The authors point out that "a jury's apportionment is entitled to deference unless it is clearly erroneous - a very lenient standard" [footnote omitted].

14 See e.g. the cursory treatments offered in two otherwise comprehensive works: Michael A Jones et al, eds, Clerk \& Lindsell on Torts, 21st ed (London, UK: Sweet \& Maxwell, 2014) at 3-88; Harvey McGregor, McGregor on Damages, 19 th ed (London, UK: Sweet \& Maxwell, 2014) at 7-003 to 7-008. Manitoba Law Reform Commission, Contributory Fault: The Tortfeasors and Contributory Negligence Act, Report No 128 (Winnipeg: Manitoba Law Reform Commission, 2013) at 11. 
the ordinary person as being just and equitable." ${ }^{16}$ Williams added: "Apportionment ... must, surely, be according to the degree of blame, not according to degree of causation, whatever that may mean." ${ }^{17}$ Stephen Chapman expressed similar sentiments. He wrote: "Causation itself is difficult enough; degrees of causation would really be a nightmare." 18 However, previous criticism of the causal potency criterion has been fairly cursory. Indeed, the pithy remarks that we have just quoted are about as far as earlier analysis has been taken in this regard. What this article adds to the literature is a systematic consideration of the law in relation to the causal potency criterion in the chosen jurisdictions and a more comprehensive argument as to why it should be shunned.

There are several preliminary observations that we should make regarding the scope of this article. First, we are not concerned with the justifiability of reducing damages for contributory negligence. Clarion calls have been made for the entire apportionment regime to be overhauled, and for plaintiff fault to be disregarded. ${ }^{19}$ Despite their importance, we cannot engage with these pleas given the narrow confines of this article. Another second issue with which we do not engage concerns contribution. ${ }^{20}$ The manner in which responsibility is apportioned between defendants for the purposes of contribution is usually governed by much the same rules as control the apportionment exercise in the law of contributory negligence. ${ }^{21}$ Our focus, however, is on contributory negligence. While we doubt that causal potency should be relevant to apportionment in the context of contribution, ${ }^{22}$ we do not advance a positive case in this regard. Third, we say nothing about other criteria to which the apportionment process should be sensitive. Arguably, it would be desirable if additional criteria were identified. ${ }^{23}$ The presence of more considerations might make the outcomes of the highly discretionary apportionment exercise more predictable. However, it is no part of the purpose of this article to suggest further factors to which reference should be made in determining the appropriate discount of damages for contributory negligence. The agenda of this article is simply to engage with the causal potency criterion.

\section{THE LAW}

In this section, we describe the law governing apportionment for contributory negligence in the chosen jurisdictions, focusing on the status of the causal potency criterion. It is

Glanville Williams, “The Two Negligent Servants” (1954) 17:1 Mod L Rev 66 at 69.

Ibid.

Stephen Chapman, “Apportionment of Liability between Tortfeasors” (1948) 64 Law Q Rev 26 at 28. Robert Stevens has recently contended that plaintiff fault should be irrelevant save where it is such that it interrupts causation: Stevens, supra note 2. Patrick Atiyah suggested that apportioning damages for contributory negligence was unjustified on the ground that it treated plaintiffs unfairly because it usually left them with uninsured losses while defendants (who are nearly invariably insured) typically bear no burden at all: Peter Cane, ed, Atiyah's Accidents, Compensation and the Law, 8th ed (Cambridge: Cambridge University Press, 2013) at 57-58. While brilliantly developed, both of these accounts are deeply controversial.

The law of contribution is addressed in David Cheifetz, "Contribution Between Negligent Tortfeasors and Unjust Enrichment: An Outline of a Solution to the 'No Benefit to B' Issue" (2016) 53:4 Alta L Rev 879.

Restatement (Third) of Torts: Apportionment of Liability $§ 23$ (2000), cmt e [Third Restatement]. For argument to this effect, see Williams, supra note 13 at 157-58.

Consider the analysis in James Goudkamp, "Apportionment of Damages for Contributory Negligence: A Fixed or Discretionary Approach?” (2015) 34:4 LS 621 (arguing that the apportionment process is problematic on account of its highly discretionary nature). 
convenient to begin with Great Britain as it is in this jurisdiction that the causal potency criterion was apparently first recognized.

\section{A. Great Britain ${ }^{24}$}

The apportionment legislation in Great Britain, like that elsewhere, is relevant only once contributory negligence is established. It specifies what is to happen once contributory fault has been proved by the defendant. The legislation stipulates:

Where any person suffers damage as the result partly of his own fault and partly of the fault of any other
person or persons, a claim in respect of that damage shall not be defeated by reason of the fault of the person
suffering the damage, but the damages recoverable in respect thereof shall be reduced to such extent as the
court thinks just and equitable having regard to the claimant's share in the responsibility for the damage.

This provision does not specify the precise manner in which the apportionment exercise is to be conducted. ${ }^{26}$ By judicial convention however, the process is as follows. First, the courts assign shares of responsibility for the plaintiff's damage to both parties. ${ }^{27}$ Those shares are specified as percentages that add up to 100 percent. ${ }^{28}$ Second, the plaintiff's damages are then reduced by the percentage of responsibility that he bears.

Just as the apportionment provision leaves it to the judges to determine the manner in which damages are to be apportioned, it does not elaborate on what the words "just and equitable" mean. The task of giving content to those words also fell to the courts. The first significant decision in this regard was that of the Court of Appeal in Davies v. Swan Motor Co. (Swansea) $L d .^{29}$ It is worth examining this decision in some detail, as it seems to be the fons et origo of the causal potency criterion. ${ }^{30}$ The plaintiff employee sustained fatal injuries when the garbage truck on which he had been riding collided with a bus. The plaintiff had been travelling on the truck's steps. The trial judge absolved the plaintiff of contributory negligence. The Court of Appeal unanimously reversed this holding. Bucknill LJ seemed to think that the only question to be asked in deciding how damages should be apportioned was: "What should be the proportions of blame?"31 His Lordship considered that the bulk of the blame lay with the driver of the bus and held that damages consequently should be reduced only by 20 percent. ${ }^{32}$ Nothing in his Lordship's reasons suggests that the causal potency of the parties' respective acts was relevant. Evershed LJ essentially agreed with Bucknill LJ. ${ }^{33}$

Williams, supra note 13 is the leading exposition of the law of contributory negligence in Great Britain. Law Reform (Contributory Negligence) Act, 1945 (UK), 8 \& 9 Geo VI, c 28, s 1(1). The Act applies in Scotland (ibid, s 5), but not in Northern Ireland (ibid, s 6). Northern Ireland has its own legislation: Law Reform (Miscellaneous Provisions) Act (Northern Ireland), RSNI 1948, c 23, s 2.

Jackson, supra note 13 (the apportionment provision "does not specify how responsibility is to be apportioned, beyond requiring the damages to be reduced to such extent as the court thinks just and equitable having regard to the claimant's share in the responsibility for the damage" at 811).

It is impermissible for a party who is held negligent or contributorily negligent not to be assigned with a share of responsibility: Jones v Livox Quarries Ltd, [1952] 2 QB 608 at 615 (CA) [Livox Quarries]. The combined percentages must not exceed 100 percent: Black v McCabe, [1964] NI 1 at 11 (CA). [1949] 2 KB 291 (CA) [Davies].

It was decided that causal potency affected apportionment for the purposes of contribution in Smith $v$ Bray (1939), 56 TLR 200 (KB Div). For criticism of Smith on this point, see JP Lawton, "Vicarious Liability of Hospital Authorities" (1947) 10:4 Mod L Rev 425 at 427-28.

Davies, supra note 29 at 313.

Ibid.

Ibid at 316 . 
It is difficult to detect any hint in his reasons that his Lordship considered causal potency to be material. However, Denning LJ wrote:

\begin{abstract}
Whilst causation is the decisive factor in determining whether there should be a reduced amount payable to the plaintiff, nevertheless, the amount of the reduction does not depend solely on the degree of causation. The amount of the reduction is such an amount as may be found by the court to be "just and equitable," having regard to the claimant's "share in the responsibility" for the damage. This involves a consideration, not only of the causative potency of a particular factor, but also of its blameworthiness. The fact of standing on the steps of the dustcart is just as potent a factor in causing damage, whether the person standing there be a servant acting negligently in the course of his employment or a boy in play or a youth doing it for a lark: but the degree of blameworthiness may be very different. ${ }^{34}$
\end{abstract}

Despite this apparent difference in approach to the apportionment exercise, Denning LJ agreed with the 20 percent discount that Bucknill LJ had suggested. It merits emphasis that Denning LJ said nothing by way of elaboration of what "causative potency" means or how one is to tell whether one party's conduct is more causally potent than the other party's.

Numerous points of considerable importance emerge from Davies. First, it is debatable whether Davies is authority for the proposition that causal potency is material to the apportionment process. Bucknill and Evershed LJJ seemed to endorse relative blameworthiness as relevant but said nothing explicit about causal potency. Only Denning LJ contended that causal potency was material. Arguably, his Lordship's reasons in this regard are inconsistent with those of Bucknill and Evershed LJJ and are hence unauthoritative. Denning LJ himself observed in a later case that "the three judgments in [Davies] do not proceed on precisely the same lines." 35

Second, Denning LJ seemed to think, as is apparent from the passage from his reasons that has been extracted, that causal potency must be relevant to apportioning damages because causation is material to whether the plaintiff is guilty of contributory negligence. ${ }^{36}$ However, this is an obvious non sequitur. ${ }^{37}$ Simply because rule $\phi$ is sensitive to a given consideration does not dictate that that consideration necessarily is also material to rule $\Psi$, even if rule $\Psi$ is associated with rule $\phi$. (For example, in the United Kingdom proximity is relevant to the existence of a duty of care, ${ }^{38}$ but it does not follow that proximity bears upon whether there has been a breach of duty.) The fact of the matter is that the question of whether a plaintiff is guilty of contributory negligence is not the same question as the size of the discount that should be imposed where contributory negligence is found. The legislation says nothing

Ibid at 326.

Livox Quarries, supra note 27 at 615.

It was, and remains, well-established that contributory fault that is causally unrelated to the damage about which the plaintiff complains is irrelevant: Lewis $v$ Denye, [1939] 1 KB 540 (CA), du Parcq LJ ("[i]n order to establish the defence of contributory negligence, the defendant must prove ... [that the plaintiff's] failure to take care was a contributory cause of the accident" at 554).

37 The same error had been committed earlier in relation to contribution. Williams was properly critical of it. He wrote that "legal fault implies causation; but the point is that apportionment should not be on the basis of causation (if such a process is logically possible)": Williams, supra note 13 at 157. Caparo Industries Plc v Dickman, [1990] UKHL 2, [1990] 2 AC 605 (HL (Eng)). 
about the former; its sole concern is with the latter. ${ }^{39}$ Because the two questions are distinct, it is perfectly possible for a given factor to be relevant to just one of them.

Third, in identifying the criteria of causal potency and relative blameworthiness Denning LJ purported to add flesh to the words "just and equitable" in the apportionment legislation. Given the supremacy of Parliament, the only legitimate way for a judge to proceed in this regard is to search for what Parliament intended by those words. However, Denning LJ engaged in no such mission. Put simply, his Lordship gave no reasons for thinking that Parliament intended the causal potency of the parties' respective acts to be relevant to the apportionment exercise. Absent such reasons, Denning LJ prima facie simply purported to add an illegitimate judicial gloss to the statute.

The central message to take away from this analysis is that Davies is dubious authority for the proposition that causal potency is relevant to apportioning damages for contributory negligence. Denning LJ offered nothing meaningful in support of his view that causal potency should be material. Despite the foregoing, many judges quickly embraced the idea that that the quantum of any reduction in the plaintiff's damages for contributory negligence should be influenced by the causal potency of the parties' respective acts. Probably the most significant decision in this regard is Stapley v. Gypsum Mines Ltd. ${ }^{40}$ Two of the five Law Lords who heard the appeal, Lords Reid and Asquith, endorsed the causal potency criterion. The other three members of the Appellate Committee, Lords Porter, Oaksey, and Tucker, remained silent in this regard. Lord Reid said:

A court must deal broadly with the problem of apportionment and in considering what is just and equitable must have regard to the blameworthiness of each party, but "the claimant's share in the responsibility ... for the damage" cannot, I think, be assessed without considering the relative importance of his acts in causing the damage apart from his blameworthiness. ${ }^{41}$

Lord Asquith sought to justify the causal potency criterion by reference to the words "as a result of" in the apportionment legislation. ${ }^{42}$ His Lordship said that this phrase "impliedly preserve[d] the doctrine" of causation. ${ }^{43}$ Plainly, this is unconvincing. This is because these words were used merely to identify the contributory negligence doctrine. The legislation isolates the rule with which it is concerned, and because the doctrine is enlivened only by causally relevant fault, it is for this reason that the legislation mentions causation. Contrary to what Lord Asquith thought, the statute, by the words "as a result of," emphatically does not stipulate, expressly or by necessary implication, that causation is relevant to the apportionment enquiry.

Despite the fact that the only judge in Stapley to attempt a rationalization of the causal potency criterion misconstrued the legislation, and although none of the judges sought to explain what the concept of causal potency involves, and notwithstanding that a majority of

This is ironically something that Denning LJ seemed to appreciate. His Lordship wrote that the apportionment provision did "not [effect] a change in the law as to what constitutes contributory negligence": Davies, supra note 29 at 322.

[1953] AC 663 (HL (Eng)) [Stapley].

Ibid at 682 .

Ibid at 687-88. Lord Denning reasoned along the same lines in Livox Quarries, supra note 27 at 615. Stapley, ibid at 687 . 
the House said nothing about causal potency, British judges have subsequently unquestioningly accepted that the causal potency of the parties' respective acts is relevant to the determination of the appropriate discount in damages for contributory negligence. The passage extracted above from Lord Reid's speech in Stapley has, in particular, often been cited, ${ }^{44}$ including at the ultimate appellate level. ${ }^{45}$ It is well established in Great Britain, therefore, that the causal potency of the parties' respective acts bears upon the apportionment exercise.

Despite the firm foothold that the causal potency criterion enjoys in the apportionment process in Great Britain, it is rare to find any judicial exposition of what, precisely, it entails. As observed, none was offered in the foundational decisions in Davies and Stapley. What little has been said in this regard suggests that the criterion is nebulous and covers much of the same territory as the relative blameworthiness criterion. In Corr, Lord Walker said that the criteria "are not precise or mutually exclusive tests." ${ }^{46}$ In Rehill v. Rider Holdings Ltd., Richards LJ, with whom Ward and Patten LJJ concurred, said that he found "it difficult to draw a clear distinction between considerations of causal potency and of blameworthiness." In Starks v. Chief Constable of Hertfordshire, Underhill LJ, with whom Moore-Bick and Patten LJJ agreed, decided that this was not a "case where any distinction can be made between the parties' relative culpability and their relative responsibility for the damage." In view of the foregoing, it is entirely unsurprising that judges, when apportioning damages, typically merely refer to the causal potency criterion in the course of arriving at a discount (if they refer to it at all) and give little, if any, indication that it influenced their determination. $^{49}$

\section{B. Australia}

All Australian jurisdictions have enacted apportionment legislation. ${ }^{50}$ The relevant provisions typically stipulate that the plaintiff's damages are to be reduced to the extent that the court considers "just and equitable having regard to the claimant's share in the responsibility for the damage." ${ }^{, 1}$ The formula in South Australia is slightly but importantly different. It states that if the plaintiff is guilty of contributory negligence, "the court must then reduce the [damages] to the extent the court thinks just and equitable having regard to the extent the contributory negligence contributed to the harm." 52 The provision in Western

See e.g. St George v Home Office, [2008] EWCA Civ 1068, [2009] 1 WLR 1670 at para 53.

See e.g. Corr v IBC Vehicles Ltd, [2008] UKHL 13, [2008] 1 AC 884 at para 44, Walker LJ [Corr]; Jackson, supra note 13 at 812.

Corr, ibid.

[2012] EWCA Civ 628, [2013] RTR 73 at para 30.

[2013] EWCA Civ 782, [2014] RTR 33 at para 17.

Among countless examples, see Laverton v Kiapasha, [2002] EWCA Civ 1656, 2002 WL 31476475 (WL UK) at para 25; Woods $v$ Police Service for Northern Ireland, [2009] NIQB 35, [2009]NIQB 35 (BaiLII) at para 36; Tafa v Matsim Properties Ltd, [2011] EWHC 1302 (QB), 2011 WL 1151874 (WL UK) at paras $166-67$.

Law Reform (Contributory Negligence and Apportionment of Liability) Act 2001 (SA), s 7 [Law Reform Act SA]; Law Reform (Contributory Negligence and Tortfeasors' Contribution) Act (WA), s 4 [Law Reform Act WA]; Civil Law (Wrongs) Act 2002 (ACT), s 102 [ACT]; Law Reform (Miscellaneous Provisions) Act 1965 (NSW), s 9 [Law Reform Act NSW]; Law Reform (Miscellaneous Provisions) Act (NT), s 16 [Law Reform Act NT]; Law Reform Act 1995 (Q1d), s 10 [Law Reform Act Qld]; Wrongs Act 1954 (Tas) [Wrongs Act Tas], s 4; Wrongs Act 1958 (Vic), s 26 [Wrongs Act Vic].

51 See Law Reform Act NSW, ibid, s 9(1)(b); Law Reform Act NT, ibid, s 16(1)(b); Wrongs Act Vic, ibid, s 26(1)(b); ACT, ibid, s 102(1)(b); Wrongs Act Tas, ibid s 4; Law Reform Act Qld, ibid, s 10.

Law Reform Act SA, supra note 50, s 7(2)(b). 
Australia is also materially different. It provides that if the plaintiff is guilty of contributory negligence, "the Court shall reduce the damages which would be recoverable by the plaintiff if the happening of the event which caused the damage had been solely due to the negligence of the defendant to such extent as the Court thinks just in accordance with the degree of negligence attributable to the plaintiff." 53

Leaving aside for the moment the apportionment provisions in South Australia and Western Australia, it should be noticed that, as is the case in relation to the British statute, the Australian legislation is silent in relation to how the apportionment process is to be carried out. It simply provides for a "just and equitable" reduction by reference to the plaintiff's "share in the responsibility for the damage." The courts are not directed to take into account or to ignore any considerations in particular. The High Court decided, however, in a series of cases that the formula used in Australia save for South Australia and Western Australia should be understood as requiring "a comparison both of culpability, i.e. of the degree of departure from the standard of care of the reasonable man ... and of the relative importance of the acts of the parties in causing the damage."54

Despite the High Court's pronouncement, subsequent cases give little indication that causal potency is actually considered by judges in apportioning damages for contributory negligence. The strong impression that one takes away from reading the cases is that judges mention the concept of causal potency and then ignore it. ${ }^{55}$ Minimal guidance can be found in the Australia cases as to what the phrase "causal potency" means. Carangelo v. State of New South Wales is one of the few cases to offer any elaboration. Adamson J said that the "defendant's superior knowledge, expertise and control over the plaintiff [resulted] in the 'causal potency' ... of the defendant's breach significantly [outweighing] that of the plaintiff's failure to take care for his own safety." 56 Another case that offers a glimpse into what the concept of causal potency might entail is Nettleton $v$. Rondeau. ${ }^{57}$ The defendant driver in this case pulled out of a driveway and into the path of the plaintiff bicyclist. The plaintiff collided with the defendant's vehicle. Hoeben CJ at CL wrote:

The defendant, as the driver of a motor vehicle ... was in control of the situation.... Her decision to enter the eastbound lane in the way in which she did, brought about the potentially dangerous situation. Accordingly, I regard the causal potency of the defendant's negligence as greater than that of the plaintiff. ${ }^{58}$

Clearly, there are but slim pickings to be found in the authorities as to what the concept of causal potency means.

Law Reform Act WA, supra note 50, s 4(1).

Podrebersek v Australian Iron and Steel Pty Ltd, [1985] HCA 34, 59 ALJR 492 at 494. See also Wynbergen $v$ Hoyts Corporation Pty Ltd, [1997] HCA 52, 72 ALJR 65 at 68. Cf Pennington v Norris, [1956] HCA 26, 96 CLR 10 at 16, which was the first case to reach the High Court concerning the construction of the apportionment legislation. In that case the High Court, in a joint opinion, stated that the legislation "must of necessity involve a comparison of culpability." It is noteworthy that no hint can be found in the Court's reasons in Pennington that causal potency is relevant.

Among countless illustrations, see Kambouridis $v$ Heyn, [2000] SASC 361 at paras 16-23; Jones v Bradley, [2003] NSWCA 81, 2003 WL 21654800 (WL Int) at para 107.

[2015] NSWSC 655, 2015 WL 3417511 (WL Int) at para 278 [citation omitted].

[2014] NSWSC 903, 2014 WL 3058447 (WL Int) [Nettleton cited to WL].

Ibid at para 81 . 
The apportionment provisions in South Australia and Western Australia have not been treated as requiring a different approach in relation to the causal potency criterion. The relevant legislative text in those jurisdictions was set out at the start of this section. That text indicates that, in South Australia, the court is required to look at the extent to which only the plaintiff's contributory negligence contributed to the damage. In Western Australia, the courts are directed to compare the parties' "negligence." Arguably, neither formulation leaves room for a consideration of causal potency. However, the courts in both South Australia and Western Australia have not understood the statutes concerned in this way. Judges in both of these states have simply chanted the mantra of causal potency, ${ }^{59}$ giving no indication that they are conscious of the fact that the legislation that they are applying is different from that elsewhere in Australia.

\section{CANADA}

Every Canadian province has enacted legislation that permits plaintiffs who are guilty of contributory negligence to recover partial damages. ${ }^{60}$ Although the wording of these statutes varies somewhat, the aim of all of the provisions is the same. In Alberta, for example, the relevant section states:

When by fault of 2 or more persons damage or loss is caused to one or more of them, the liability to make good the damage or loss is in proportion to the degree in which each person was at fault but if, having regard to all the circumstances of the case, it is not possible to establish different degrees of fault, the liability shall be apportioned equally. ${ }^{61}$

\section{The Ontario legislation provides:}

In any action for damages that is founded upon the fault or negligence of the defendant if fault or negligence is found on the part of the plaintiff that contributed to the damages, the court shall apportion the damages in proportion to the degree of fault or negligence found against the parties respectively.

If it is not practicable to determine the respective degree of fault or negligence as between any parties to an action, such parties shall be deemed to be equally at fault or negligent. ${ }^{62}$

Comparable provisions exist in the other common law provinces. ${ }^{63}$

See e.g. Messenger v Toll Holdings Ltd, [2002] SASC 376, 37 MVR 442 at paras 17-19; Port Hedland (Town of) v Hodder (No 2), [2012] WASCA 212, [2013] 294 ALR 315.

Contributory Negligence Act, RSA 2000, c C-27 [Alberta Contributory Negligence Act]; Negligence Act, RSBC 1996, c 333; The Tortfeasors and Contributory Negligence Act, RSM 1987, c T90 [Manitoba Contributory Negligence Act]; Contributory Negligence Act, RSNB 2011, c 131; Contributory Negligence Act, RSNL 1990, c C-33; Contributory Negligence Act, RSNS 1989, c 95; Negligence Act, RSO 1990, c N1 [Ontario Negligence Act]; Contributory Negligence Act, RSPEI 1988, c C-21; The Contributory Negligence Act, RSS 1978, c C-31. Regarding Quebec, see Civil Code of Québec, art 1478 CCQ. In relation to the Territories, see Contributory Negligence Act, RSNWT 1988, c C-18; Contributory Negligence Act, RSY 2002, c 42.

Alberta Contributory Negligence Act, ibid, s 1(1).

Ontario Negligence Act, supra note 60, ss 3-4.

The Alberta-type wording is found in British Columbia, New Brunswick, Newfoundland, Nova Scotia, Prince Edward Island, and Saskatchewan. Manitoba Contributory Negligence Act, supra note 60, has slightly different wording. Section 4 reads:

Contributory negligence by a plaintiff is not a bar to the recovery of damages by him and in any action for damages that is founded upon the negligence of the defendant, if negligence is found on the part of the plaintiff which contributed to the damages, the court shall apportion the damages in proportion to the degree of negligence found against the plaintiff and defendant respectfully. 
It should be noted that none of these provisions refers to causal potency. The size of the reduction in damages for contributory negligence is instead to be determined by reference to the parties' respective degree of "fault" or "negligence." One could perhaps argue that the word "fault" permits consideration of causal potency. However, such an argument would be difficult to sustain, at least in relation to certain statutes. For example, the Alberta-type provision distinguishes between the concepts of fault and cause, and so it would be implausible to suggest that the legislature intended fault to include considerations of causation.

In view of the legislative formulae, it is entirely unsurprising that Canadian jurisprudence has rejected unequivocally the proposition that causal potency is relevant to the apportionment of damages. For example, in Clyke v. Blenkhorn the Nova Scotia Court of Appeal said that "[t]he prevailing Canadian practice" in apportioning damages "is to look at ... relative or comparative blameworthiness or culpability, i.e., to see in what degrees the parties departed from the norm of reasonable conduct." ${ }^{64}$ In Heller v. Martens ${ }^{65}$ Justice Fruman, after considering the point thoroughly, concluded that the relative blameworthiness criterion is the only criterion that is relevant in determining the appropriate reduction in damages for contributory negligence. ${ }^{66}$ Justice Fruman rejected the relevance of causal potency, and described that criterion as "a poor choice." ${ }^{.67}$ There are many other cases in which similar remarks have been made. ${ }^{68}$

\section{UNITED STATES ${ }^{69}$}

As with the other common law jurisdictions discussed in this article, all jurisdictions in the United States initially embraced the all-or-nothing approach to contributory negligence. Gradually, that rule was rejected in most states, sometimes by legislation and on other occasions by judicial fiat, in favour of apportionment. ${ }^{70}$ The apportionment regime is known in the United States as "comparative negligence" or "comparative fault," in contradistinction to "contributory negligence," that label generally being reserved for the common law rule. Speaking very broadly, comparative negligence systems come in two models. One model, which is known as "pure comparative negligence," permits the plaintiff's damages to be reduced for his or her contributory negligence regardless of whether the plaintiff's share of

(1958) 13 DLR (2d) 293 at 304 (NSCA) [emphasis in original]. Justice MacDonald was speaking for himself and Justice MacQuarrie. 2002 ABCA 122, 213 DLR (4th) 124.

Justice Hunt concurred. Justice O'Leary agreed with Justice Fruman's articulation of the relevant principles (ibid at para 54) but dissented in relation to their application.

Ibid at para 22 .

Another case that warrants particular attention is the oft cited decision in Cempel v Harrison Hot Springs Hotel Ltd (1997), [1998] 6 WWR 233. In this case Justice Lambert (with whom Justice Esson agreed) said that apportioning damages for contributory negligence based on an assessment of relative degrees of causation "is wrong in law" and that "we are not assessing degrees of causation, we are assessing degrees of fault" (ibid at para 19). Further cases on point include Briante (Litigation Guardian of) $v$ Vancouver Island Health Authority, 2014 BCSC 1511, 14 CCLT (4th) 204; Nanaimo-Ladysmith School District No 68v Dean (Litigation guardian of), 2015 BCSC 11, 16 CCLT (4th) 250; Paquette (Litigation guardian of) v School District No 36 (Surrey), 2014 BCCA 456, [2015] 5 WWR 737. See Klar, supra note 8 at 544, n 67; David Cheifetz, Apportionment of Fault in Tort (Aurora, Ont: Canada Law Book, 1981) 99-104 (for further relevant case law).

The leading treatment of contributory negligence and apportionment in the United States is Victor Schwartz, Comparative Negligence, 5 th ed (New Providence, NJ: LexisNexis, 2010).

For a masterful description of the transition from the all-or-nothing rule to apportionment in the United States, see John G Fleming, "Comparative Negligence at Last: By Judicial Choice" (1976) 64:2 Cal L Rev 239. 
responsibility for the damage exceeds that of the defendant. The other model, which is referred to as "modified comparative fault," permits apportionment only where the plaintiff"s responsibility for the damage does not exceed a particular percentage, often 50 percent. $^{71}$

How is the size of the discount for contributory negligence determined in the United States? It is convenient to answer that question by reference to the Restatement (Third) of Torts: Apportionment of Liability. Section 7 states:

\begin{abstract}
Plaintiff's negligence (or the negligence of another person for whose negligence the plaintiff is responsible) that is a legal cause of an indivisible injury to the plaintiff reduces the plaintiff's recovery in proportion to the share of responsibility the fact finder assigns to the plaintiff (or other person for whose negligence the plaintiff is responsible). ${ }^{72}$
\end{abstract}

\title{
Section 8 provides:
}

Factors for assigning percentages of responsibility to each person whose legal responsibility has been established include

the nature of the person's risk-creating conduct, including any awareness or indifference with respect to the risks created by the conduct and any intent with respect to the harm created by the conduct; and the strength of the causal connection between the person's risk-creating conduct and the harm. ${ }^{73}$

The Restatement thus adopts the position that "the strength of the causal connection," which is what courts in other jurisdictions call causal potency, is a relevant factor in the apportionment process. ${ }^{74}$ How has this criterion been understood and applied in practice? As is the case in the other common law jurisdictions that invoke the notion of causal potency, there is little guidance available. ${ }^{75}$ The Reporters of the Restatement write that " $[\mathrm{t}] \mathrm{he}$ comparative strength of the causal connection between the conduct and the harm depends on how attenuated the causal connection is, the timing of each person's conduct in causing the harm, and a comparison of the risks created by the conduct and the actual harm suffered by the plaintiff." 76 This remark is perhaps not terribly far from saying that the strength of the causal relationship depends on the strength of the relationship. Furthermore, this passage does not really assist in separating the causal potency criterion from that of relative

A very extensive literature has sprung up as to which of these models is superior: see e.g. John W Wade, “A Uniform Comparative Fault Act: What Should it Provide?" (1977) 10:2 U Mich JL Ref 220; Richard N Pearson, "Apportionment of Losses Under Comparative Fault Laws: An Analysis of the Alternatives" (1980) 40:2 La L Rev 343; David C Sobelsohn, “'Pure' vs. 'Modified' Comparative Fault: Notes on the Debate" (1985) 34:1 Emory LJ 65; William E Westerbeke, "In Praise of Arbitrariness: The Proposed 83.7\% Rule of Modified Comparative Fault" (2011) 59:5 U Kan L Rev 991.

Third Restatement, supra note $21, \S 7$.

Ibid, \&8.

Cf Schwartz \& Rowe, supra note 69 at 60 who write: "Under pure comparative negligence, the plaintiff's contributory negligence is taken into account by reducing his award in proportion to his fault" [footnote omitted].

75 Robert N Strassfeld "Causal Comparisons" (1992) 60:5 Fordham L Rev 913 at 947 observes that the concept is "underdeveloped" and that "[m]any courts discuss the question offhandedly. They note that causal comparison is called for in a particular case, but they fail to articulate their understanding of what the comparison entails."

76 Third Restatement, supra note $21, \S 8$, cmt c. We note en passant that the suggestion that the timing of the parties' acts should be taken into account harks back to the discredited last clear chance doctrine. 
blameworthiness. In large part, the Reporters' explanation of the concept of causal potency points to matters that might readily be relevant to the issue of relative blameworthiness.

It is interesting to note that the causal potency criterion frequently arises for consideration in the United States in product liability litigation, ${ }^{77}$ a field in which strict liability is often imposed. The issue of causal potency is raised particularly acutely in this context because there may be no fault on the part of the defendant in which case a comparison of relative blameworthiness is impossible. ${ }^{78}$ When this is so, causal potency is the only criterion used in apportioning damages. Even then, however, the courts generally simply assert that the plaintiff's damages are to be reduced in proportion to the plaintiff's causal contribution to the injury. ${ }^{79}$ In Murray, which is a leading case in this context, the court merely said that the comparison must focus "on the role each played in bringing about the particular injury." 80 In short, precisely how this determination is to be made remains obscure. ${ }^{81}$

\section{The Causal Potency Criterion Evaluated ${ }^{82}$}

To this point, our goal in this article has been to describe the role that the causal potency criterion plays in the jurisdictions with which we are concerned. Our aim now shifts. The purpose of this short section is to consider whether that criterion should be considered in apportioning damages for contributory negligence. Before engaging with that question, it is worth stressing two points that emerge clearly from our review of the law. The first is that judges have never really explained what the causal potency criterion involves. Judges themselves have complained that the concept is vague and nebulous. The second is that, except in the case of Canada, where the causal potency criterion has no foothold in the law, judges usually mention the causal potency criterion only in passing. Consequently, it is doubtful whether it is really taken into account. These twin points obviously do not bode well for the suggestion that the causal potency of the parties' respective acts should be relevant to apportionment. How can it seriously be suggested that a concept that apparently has no content and which is largely ignored even in jurisdictions that have formally embraced it should be accepted? A concept which is empty and quietly overlooked adds needlessly to the size of the law. The criterion is at best a mere surplusage. At worst it is an unwelcome distraction which provokes barren disputes and which increases the already considerable uncertainty that afflicts the process of apportioning damages for contributory negligence. "A strong majority of jurisdictions" recognize contributory
Restatement (Third) of Torts: Products Liability § 17, cmt a.

Strassfeld, supra note 75 at 949 argues where "the standard of liability denies us commensurable faults to compare, as in strict products liability cases, we ought to apportion on the basis of causal weight" [footnote omitted]. In Murray v Fairbanks Morse, 610 F (2d) 149 (3rd Cir 1979) [Murray] the Court stated that where liability is to be apportioned between a manufacturer and a consumer, "the only conceptual basis for comparison is the causative contribution of each to the particular loss or injury" (ibid at 159).

79

80

Murray, supra note 78 at 159-60.

See the valuable discussion by Judge Linde in Sandford v Chevrolet Division of General Motors, 642 P (2d) 624 (Or 1982). Judge Linde wrote that he was "not persuaded that the concept of "comparative causation' is more cogent or meaningful than comparative fault, if by 'causation' is meant some relation of cause and effect in the physical world rather than the very attribution of responsibility for which 'causation' is to serve as the premise" (ibid at 630).

We are grateful to Richard Wright for discussing with us the ideas that we advance in this section. 
The foregoing considerations would seem to be fatal to the causal potency criterion. However, there is a more fundamental point that can be put against it. The criterion implies that there can be degrees of causation. Is this intelligible? We doubt that one can speak meaningfully of degrees of causation. Something is or is not a cause of the plaintiff's injury. As Richard Wright puts it:

Causation, unlike the level or foreseeability of the risk or most of the other factors relevant to responsibility, is not a matter of degree. Some condition either was or was not a cause (in the proper scientific sense) of a particular injury. There is no way, based purely on causation, to identify one cause of an injury as more important or significant than any other cause of the same injury... True "causal apportionment" is conceptually meaningless. $^{83}$

Most fundamentally, therefore, the difficulty with the concept of causal potency is that it is simply confused. It calls on the court to do something that is impossible.

\section{CONCLusion}

Canadian courts have unequivocally rejected causal potency as a factor in apportioning damages for contributory negligence. The law in Canada stands in stark contrast in this regard to that in Great Britain, Australia, and the United States. The Manitoba Law Reform Commission has recently recommended that the law in Canada be changed so that it conforms to that in these other jurisdictions. However, nothing was said by the Commission in support of this recommendation beyond the assertion that taking cognizance of the causal potency of the parties' respective acts would introduce greater flexibility into the law. For the reasons that have been given in this article, the Commission's recommendation should be rejected. 